\title{
Transpositions of maxillary canines. Periodontal aspects and orthodontic therapy
}

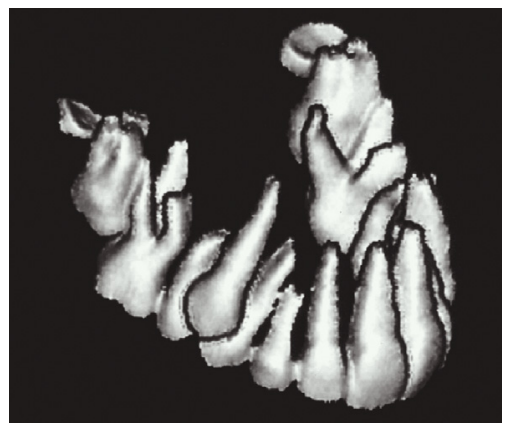

\section{Laurent DELSOL, Valerie ORTI, Manon SERRE, Pierre CANAL}

\begin{abstract}
The exchange of position of two adjacent teeth constitutes a transposition. Maxillary canines are rarely affected; transpositions of upper canines occur in only $.2 \%$ of the orthodontic population. They can be detected early in radiographic examinations and later, clinically, after they begin to erupt. Most writers affirm that transpositions, which are often associated with other dental anomalies, are caused primarily by some genetic defect but that local factors may contribute to their development. Practitioners should consider their muco-gingiva environment as an important factor in their evaluation of the iatrogenic risks that might accompany treatment and consider improving soft tissue status as a preparatory soft tissue therapeutic procedure. They must also differentiate between cases of incomplete transposition and partial complete transposition, which can almost always be successfully treated, from cases of total complete transposition that are relatively difficult if not impossible to treat.
\end{abstract}

\section{KEYWORDS}

Transposition

Canine

Periodontium

Orthodontic mechano-therapy. 


\section{1 - INTRODUCTION}

Transpositions of maxillary canines, which occur quite infrequently, can be detected before they erupt on routine X-Ray examination, notably on panoramic films, or found clinically after they do erupt. (fig. 1).

Even though it is rare, the phenomenon is far from a recent development. Nelson $^{45}$ in 1992 and Lukacs ${ }^{37}$ in 1998 showed transpositions on crania that were more than 5000 years old (fig. 2).

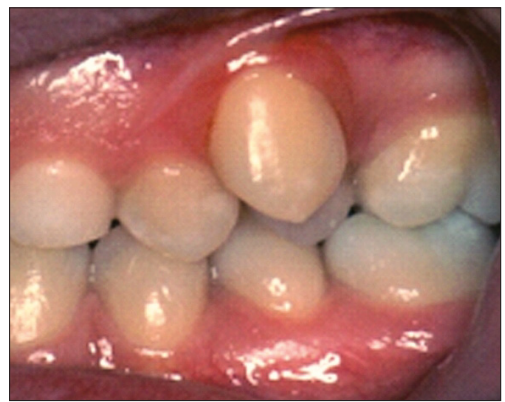

Figure 1

Intraoral view of a canine transposed with a first premolar.

\section{2 - DEFINITION}

A transposition is usually defined as a rare dental phenomenon in which two adjacent teeth in the arch exchange places (fig. 3).

S. and L. Peck, in 1995, proposed a "common" definition, asserting that a transposition was an exchange of position of two adjacent teeth, especially of their roots. It could also be the eruption of a tooth into a position usually occupied by a non-adjacent tooth.

But in extreme cases of ectopic eruption of permanent teeth that change the natural arch positioning, the term employed is transmigration.
As early as 1817, a French dentist named $\mathrm{Miel}^{42}$ reported a case of transposition.

To begin with, we shall define what is meant by transposition and then we shall discuss how frequently it occurs, its association with other anomalies, and, then, the consequences it has for periodontal status before we describe and evaluate the orthodontic means that are used to deal with it.

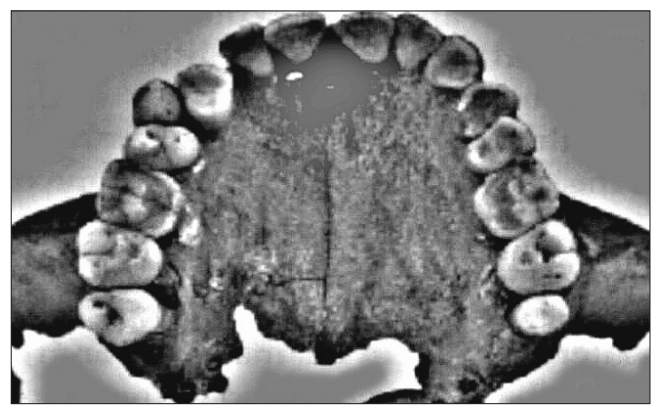

Figure 2

Occlusal view of a transposition in a 5000 year old cranium.

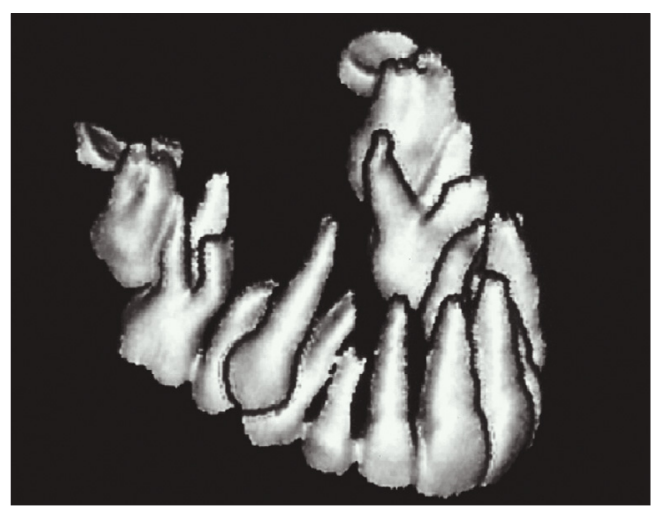

Figure 3

Three dimensional reconstruction of a transposition. 
Peretz ${ }^{55}$, in 1992, differentiated complete transposition where both crowns and roots changed position from incomplete transposition where only the crown is transposed.

\section{3 - FREQUENCY AND CLASSIFICATION}

In the $.2 \%$ of the orthodontic population in which transpositions are found ${ }^{18,5759,60}$, maxillary canines, according to Peck, are involved 97\% of the time.

- Peck's classification, $1995^{50}$ (fig. 4)

The transposition most frequently encountered is between the canine and the first premolar, $71 \%$ of the time, and canine with lateral incisor, $20 \%$ of the time. Occasionally bilateral, these transpositions are usually unilateral and occur more frequently in females than in males ${ }^{49,51,54,57}$.

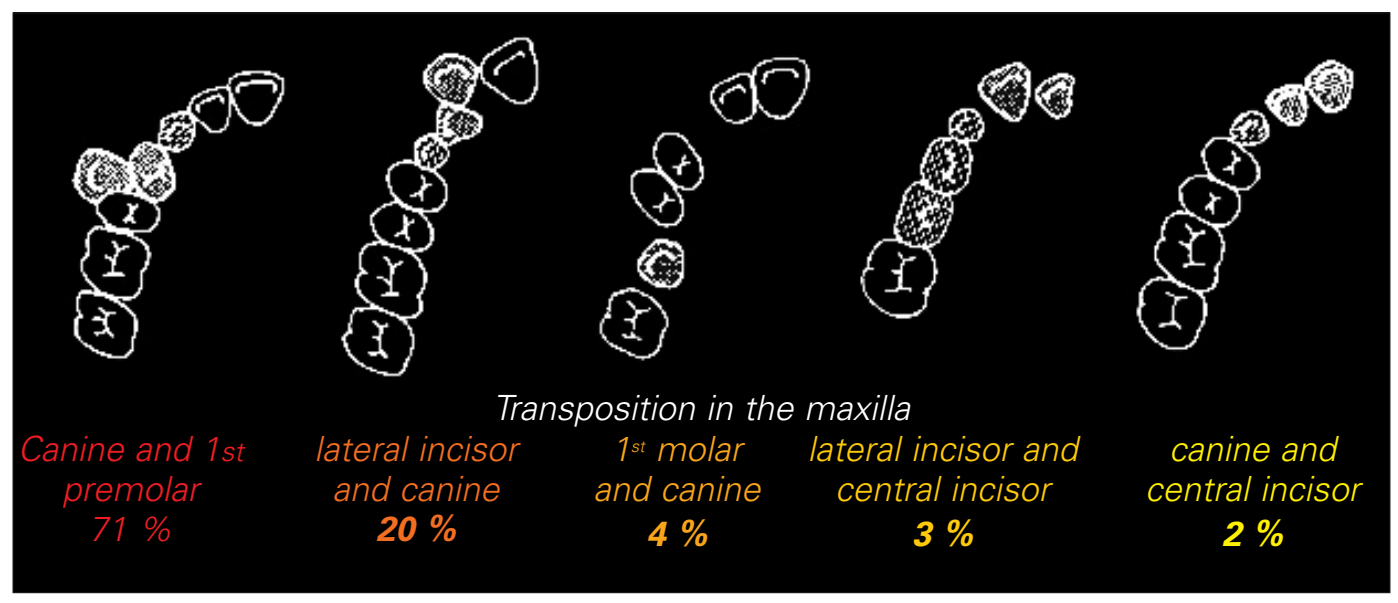

Figure 4

\section{4 - ETIOLOGY}

Most authors, with S. and L. Peck ${ }^{49,50}$, the principals among them, assert that transpositions have a genetic origin but that a variety of local factors can contribute to their development.

Only Plunkett ${ }^{57}$ disagrees with this genetic hypothesis.

Other possible causes of transposition that have been advanced include:
- The exchange of positions of tooth buds at an early stage of dental development ${ }^{28}$.

- The failure of the root of a temporary canine to resorb, causing the permanent tooth bud to move to another position 35,38,2,68.

- A mechanical deflection if the eruptive path is disturbed $26,38,56$. 
- The loss of adjacent teeth $49,50,51,52,53,54$.

- The presence of an odontoma61.

- The presence of a cystic lesion ${ }^{3}$.

These widely varying conjectures reinforce the consensus that the ori- gin of transpositions is primarily genetic but that local factors may contribute to their development.

\section{5 - TRANSPOSTIONS AND ANOMALIES ASSOCIATED WITH THEM}

Transpositions of maxillary canines are frequently associated with other dental anomalies:

- congenitally absent teeth, particularly upper lateral incisors in 37 to $48 \%$ of $\operatorname{cases}^{18,19,29,49}$ (fig. 5);

- reductions in size of adjacent teeth, in the form of dwarfed or pegshaped laterals in 10 to $25 \%$ of the cases $^{18,19,29,49}$ (fig. 6);

- it would seem in addition, from clinical observation, that in cases of

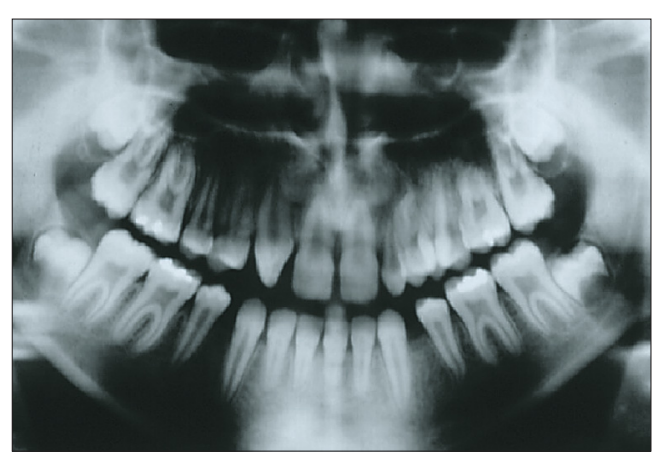

Figure 5

A case with agenesis of the upper lateral incisors.
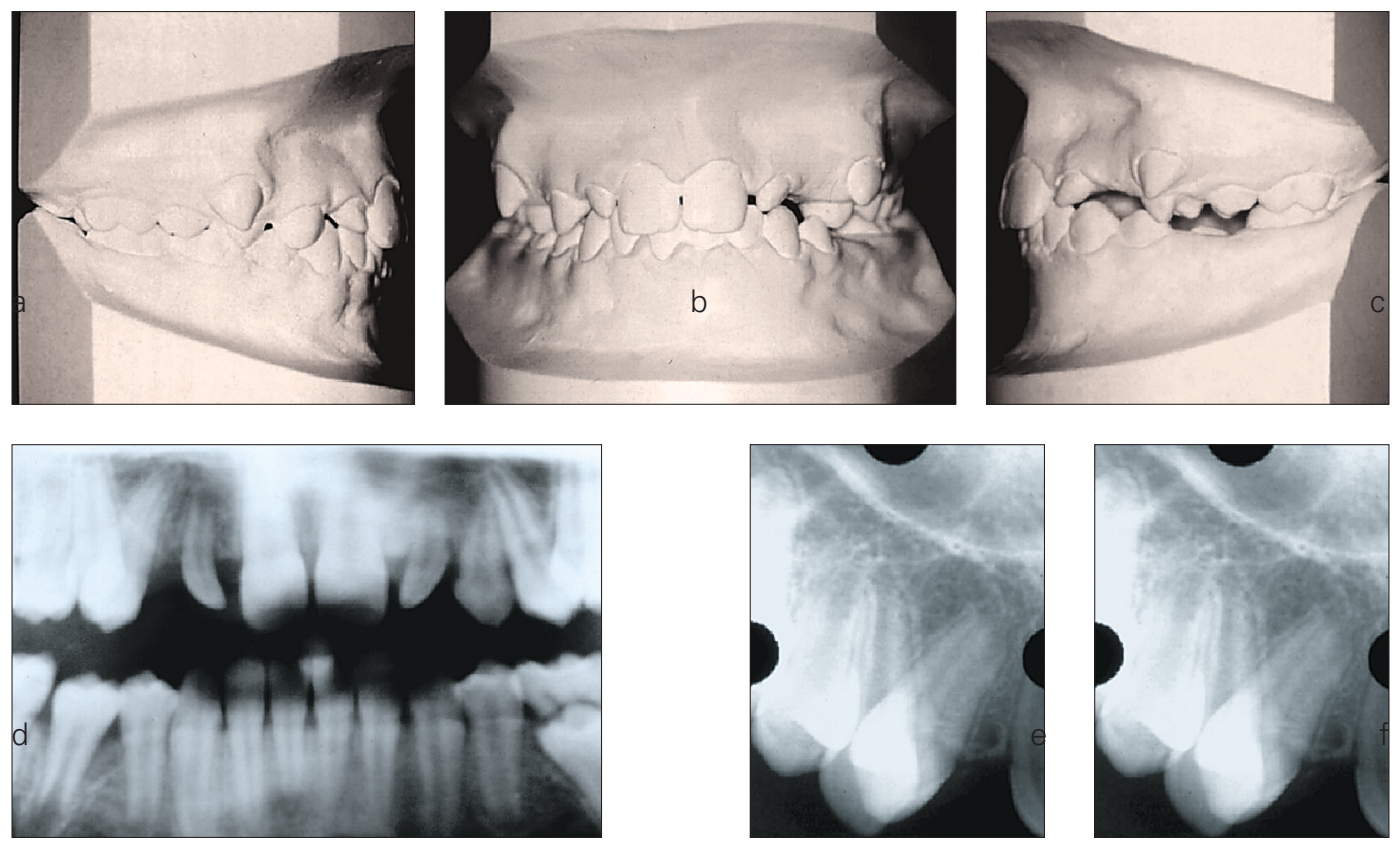

Figures 6 a to $f$

- a to $c$ frontal and lateral photos of the models;

$-d$ : a panoramic X-ray film showing the bilateral transpositions of the canines and the 1st premolars and also the peg-shaped lateral incisors;

- e to f: periapical films of the upper right and left transposed canines and 1st premolars. 
dental anomalies the risk of root resorption is great, but no statistical evidence to prove this has as yet been shown in the literature. Clinicians, however, should be aware of this possibility and guard against it ${ }^{47}$.

\section{6 - THE PERIODONTAL ENVIRONMENT OF TRANSPOSITIONS}

The environment and nature of the muco-gingival tissues investing the teeth are factors upon which longterm periodontal health depends. Korbendau and Guyomard in $1980^{30}$ showed clinical examples of keratinised gingiva following teeth in their movements. Using a multi-disciplinary approach to orthodontic treatment, surgical technique and reinforcement of periodontal health should be of concern in all stages of mechanotherapy.

During orthodontic treatment periodontal tissue is routinely subjected to stress that can be iatrogenically harmful especially if that tissue is fine in texture, type II or IV according to the Maynard and Wilson ${ }^{40}$ classification. Inattention to periodontal health can lead to gingival recession or even chronic inflammation. These harmful phenomena are often intensified by deposits of biofilm resulting from the difficulty in controlling plaque around the orthodontic appliance.

So orthodontic therapists should plan on muco-gingival care from the outset of therapy with the goal of restoring a thickened keratinised gingiva over thin cortical plates or, even more important, of areas of dehiscence to encourage osseous reconstruction throughout the course of orthodontic therapy ${ }^{32}$.

\section{6 - 1 - During the initial phase}

Depending on the quality of the soft tissue investing the canine, prac- titioners should select from a variety of possibilities, the most appropriate way to deal with $i^{36}$.

\section{- An apically positioned flap}

In early treatment ${ }^{41}$, surgical uncovering is the best approach. With it keratinised tissue can be displaced apically from a flap of partial thickness of the original gingival layer. The surgeon can center this flap and suture it directly over the enamel of the buccal surface of the exposed canine crown ${ }^{20}$.

\section{- Periodontal plastic surgery}

By proper preparation of keratinised gingiva before treatment begins, orthodontists can avoid any denudation of the canine root surface during treatment and reduce the danger of an inflammatory tissue response ${ }^{31}$.

The primary ways of supporting soft tissue are the epithelial conjunctive tissue surface or pedicle graft and the embedded conjunctive tissue graft $^{13}$.

\section{- The epithelial conjunctive tissue graft}

This requires the autogenous transplantation of an epithelial conjunctive tissue graft, most frequently taken from the palate and placed near the cemento-enamel junction, thus insuring a stable periodontal environment. This surgical technique that Bjorn first described in 1963 is rarely used today in the upper anterior region, where aesthetics are a primary consideration, because it leaves a residue of scar tissue that does not 
harmonize with the gingiva around adjacent teeth. Still, when a patient's smile does not uncover that region, dentists can use it with confidence.

\section{- The embedded conjunctive tissue graft}

This technique for management of periodontal tissues is used primarily in areas where aesthetics is an important consideration. The graft is placed between the periosteal bed and the existing gingiva. The flap serves to make a hermetic seal over the conjunctive tissue graft, covering the treated area and constituting a surface compatible with the adjacent gingival tissue. This technique gives generally successful and readily reproducible results both aesthetically and functionally. A variant to this technique, which consists of burying the graft under a laterally placed flap, is used when buccal gingival height is limited and a suitable adjacent site is available.

\section{6 - 2 - During orthodontic treatment}

If the root of a canine begins to become exposed during the course of orthodontic treatment or if a persistent gingival inflammation becomes evident orthodontists can choose from two therapeutic stances ${ }^{24}$ :

- if they determine that an orthodontic force vector is the iatrogenic cause of the difficulty ${ }^{22}$ they

\section{7 - ORTHODONTIC TREATMENT}

It is important to differentiate between cases of incomplete transposition, usually between maxillary lateral incisors and canines, which can almost always be successfully treated might be able to adjust that force and wait until the close of mechanotherapy and treat the soft tissue problem under optimal conditons ${ }^{34}$;

- but if it is impossible to remove the source of the irritant causing the denudation in an effective and orderly fashion or if the aesthetic defect is great, they may want to immediately restore the periodontium by one of the techniques already described.

\section{6 - 3 - After orthodontic treatment}

If the tissue recession appears after the once transposed canine has been placed in its correct position in the arch, it is probably the result of a late developing secondary consequence of orthodontic traction that transforms type III periodontium, weakened by underlying bone loss with no associated mucogingival default, into type IV4. If the bone loss has not affected the interproximal septa, a $100 \%$ recovery of gingival tissue can be anticipated. The most effective surgical approach is a submerged connective tissue graft under a flap positioned over the crown. The tunnelised conjunctive tissue graft that Azzi described in $1998^{10}$ is an excellent technique for preserving the integrity of gingival papillae and a method of displacing the correct amount of healthy tissue.

and cases of complete transposition, which are relatively difficult to correct, especially if the canine is fully erupted and has taken its place in the curvature of the arch. 


\section{7 - 1 - Incomplete maxillary transpositions}

Orthodontists can almost always treat these incomplete transpositions, which are usually between maxillary laterals and canine teeth, successfully because while their crowns are transposed to varying extents their roots usually remain in their proper sites.

Mechano-therapy, which always employs light forces, can be of two types, one leaving a relative liberty to the affected teeth to slide back into their correct positions and the other to exert more direct "controlling" force in order to guide the movement of the transposed tooth as perfectly as possible (fig. 7).

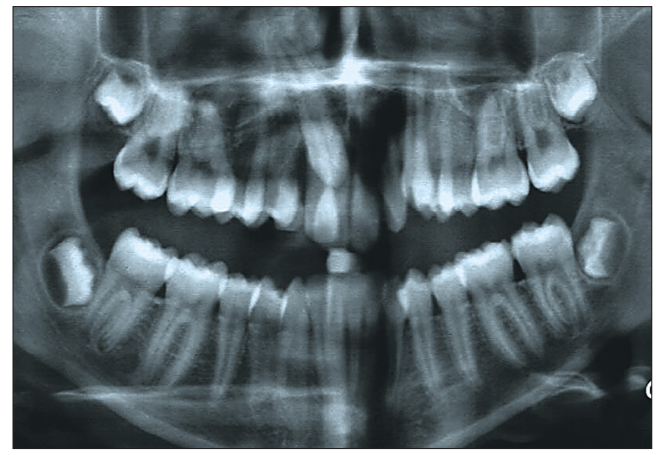

a

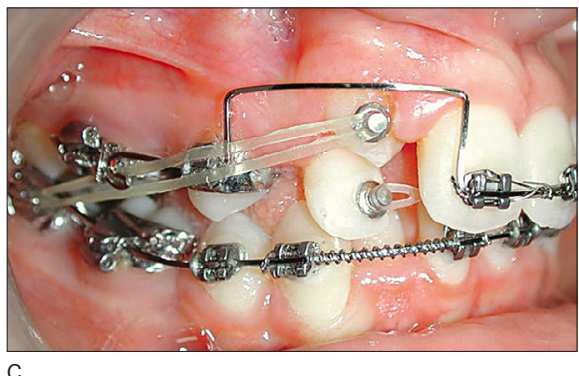

C

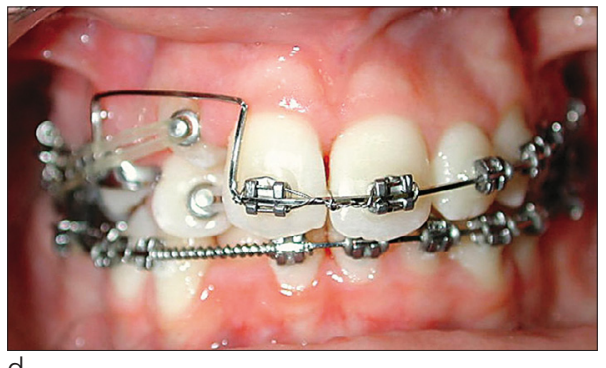

Figures 7 a to e
The incomplete transposition, following trauma, of a maxillary canine whose crown erupted in the position of the central incisor but whose root remained effectively in the canine site is a special case ${ }^{58}$. After evaluating the problem with a set-up, the orthodontist was emboldened to make the unusual decision that the best course of action in this case was to replace the central incisor lost in a traumatic accident with the canine, and accept an end of treatment asymmetrical molar occlusion, class II on the left, Class I on the right, which would require careful equilibration. Of course, the canine would have to be modified cosmetically, during and after orthodontic treatment, to allow it to play its role as a central incisor successfully. (fig. 8).
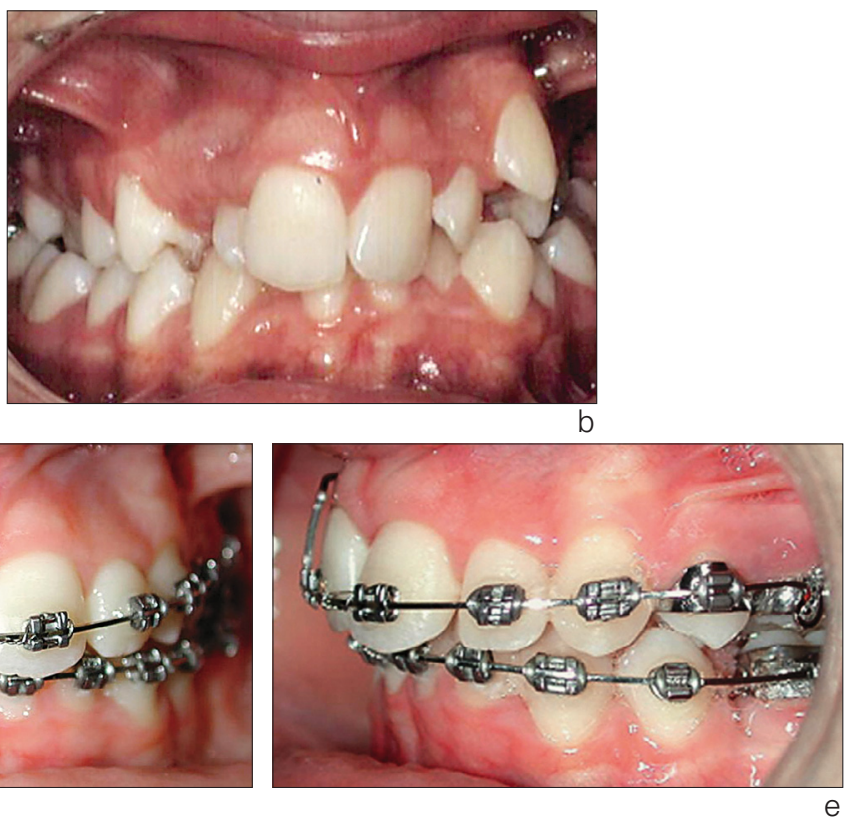

e

$a$ and b: panoramic film and intraoral view of transposed upper lateral and canine;

c to e: orthodontic appliance designed to correct transposition with light force (case treated by Dr. P. Planché). 

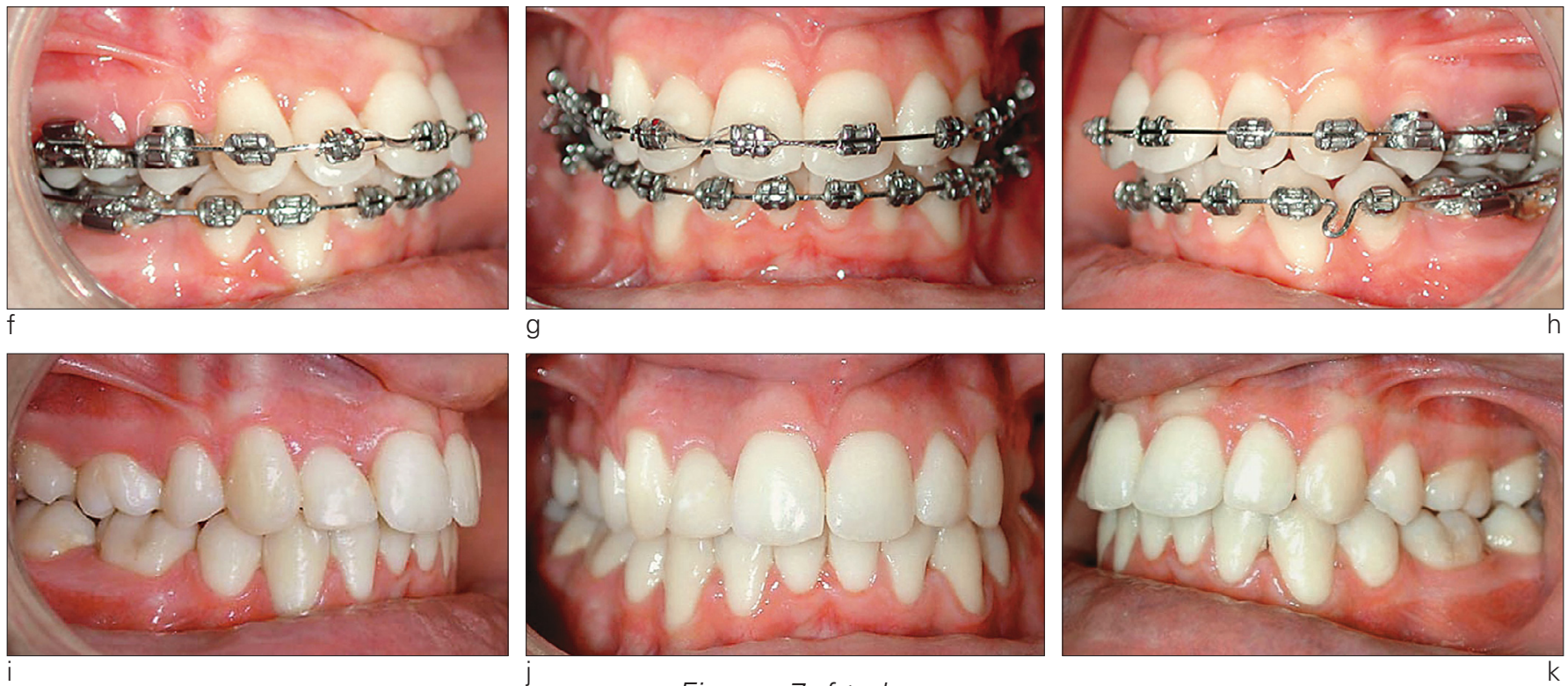

$f$ to $h$ : interdigitation with finishing appliance;

Figures 7 to $k$

i to k: intraoral views at end of treatment (case treated by Dr. P. Planché).

\section{7 - 2 Complete maxillary trans- positions}

It is important to differentiate between cases of partial complete transposition where the transposed tooth remains outside the curvature of the arch that can be treated orthodontically and cases of total complete transposition where the

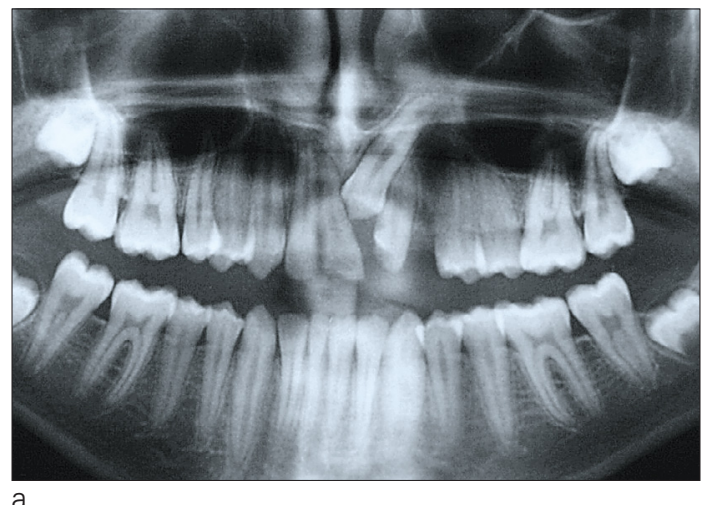

Figures $8 a$ and $b$

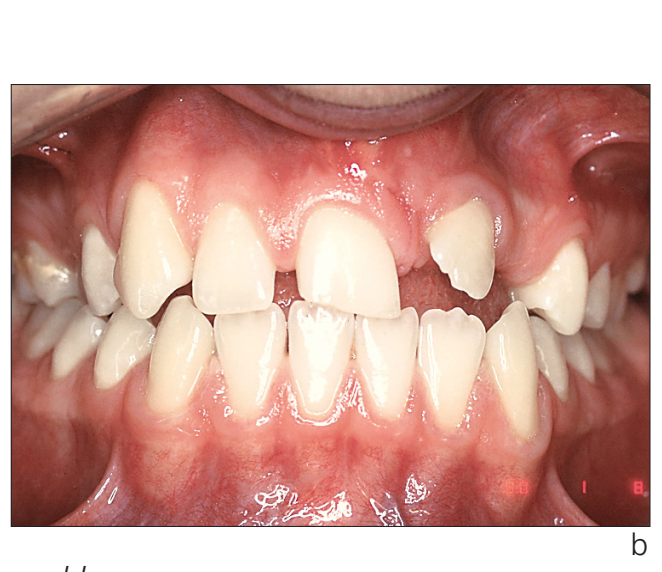

b

\section{7 - 3 Complete total transpositions}

These complete total transpositions are almost always between canines and first premolars.

tooth lies within the curvature of the arch and is virtually impossible to treat orthodontically.

Panoramic film and intra-oral view at the beginning of treatment of a maxillary left canine transposed in the central incisor position (case treated by Dr. J.-J. Aknin.). 

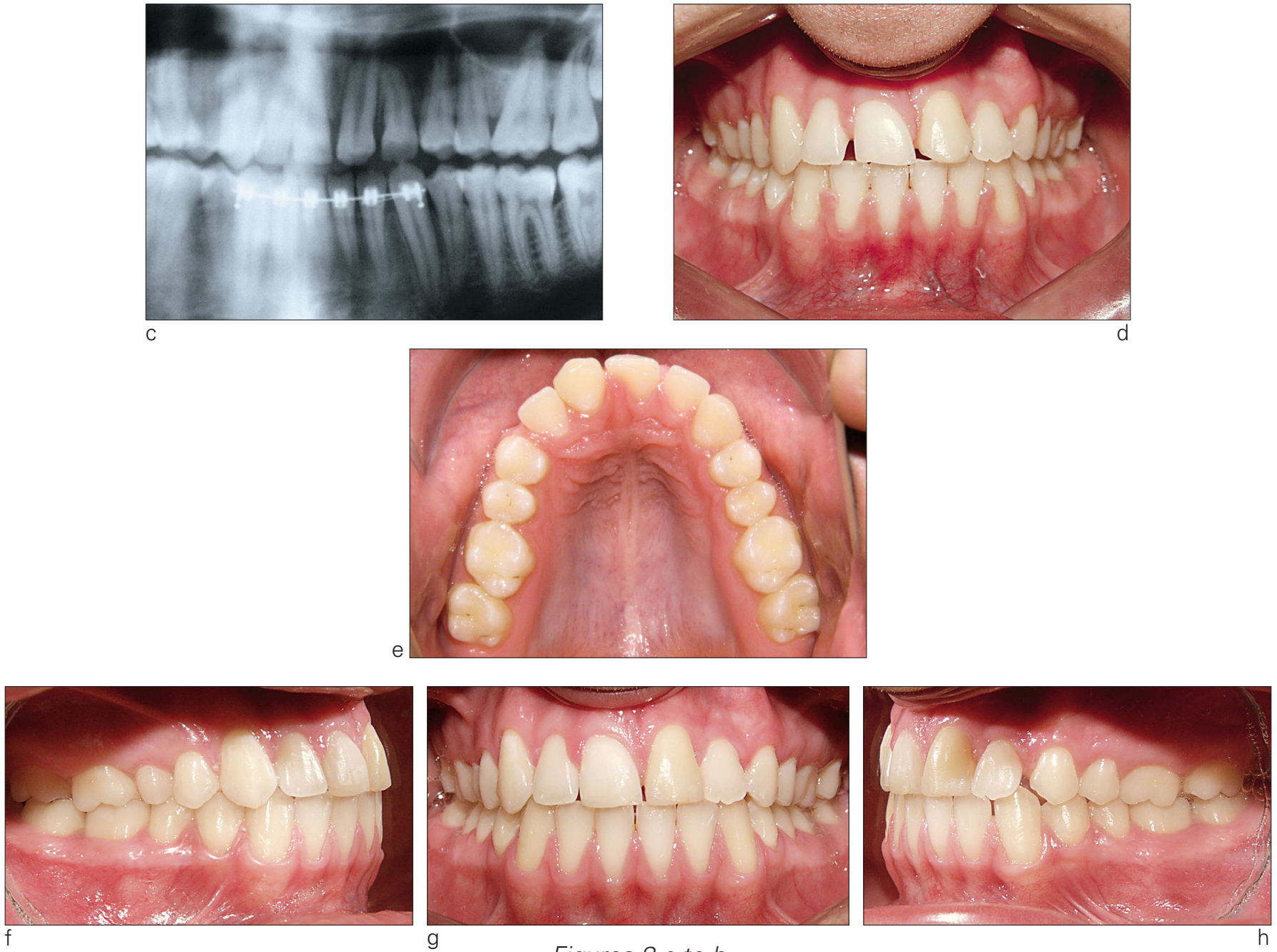

Figures $8 \mathrm{c}$ to $h$

$c$ and d: end of orthodontic treatment with left canine in place of left central incisor;

e: occlusal intraoral view at the end of orthodontic treatment;

$f$ to h: intraoral views after cosmetic facing has been bonded to canine in incisor position (case treated by D. J.-J. Aknin.)

Every writer $17,47,48,50,62,63,66$ dealing with this subject has proposed that a transposed canine sometimes be left in place for multiple reasons, the difficulty of moving it and the risks of root resorption, of tissue damage, and loss of pulpal vitality that such movement might entail.

A canine tooth left in its transposed position is aesthetically acceptable especially if it is modified cosmetically to resemble a premolar if it is reshaped to adapt to the occlusion in that position. Most transposed teeth dealt with in this way pose no aesthetic or functional problems but do work best, after appropriate equilibration, as participants in group function. (fig. 9). 


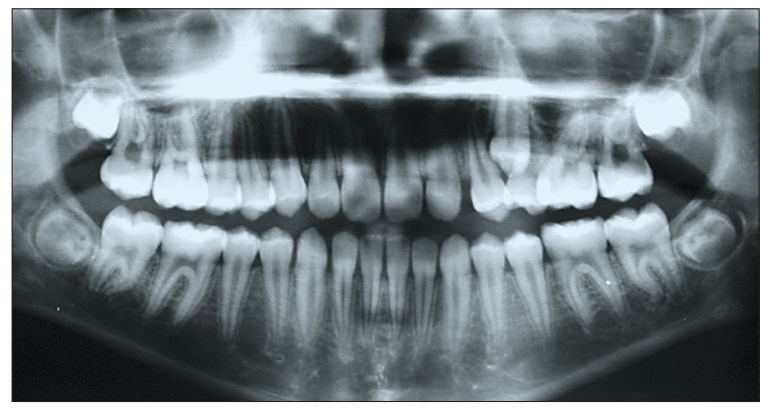

a

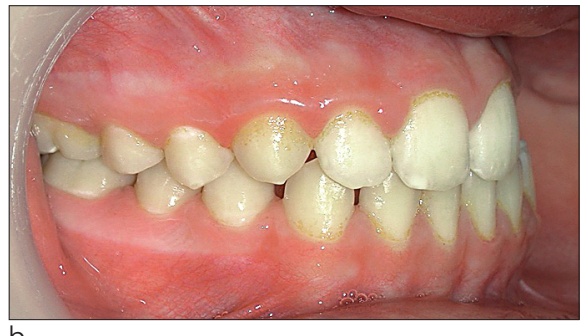

$\mathrm{b}$

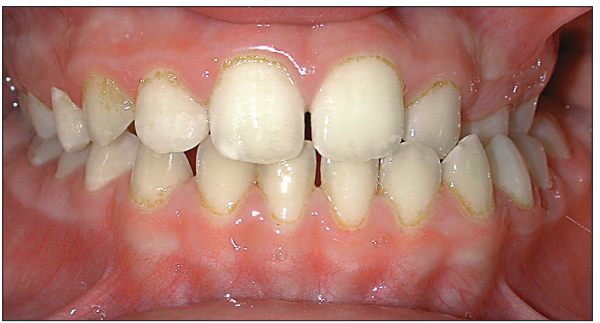

C

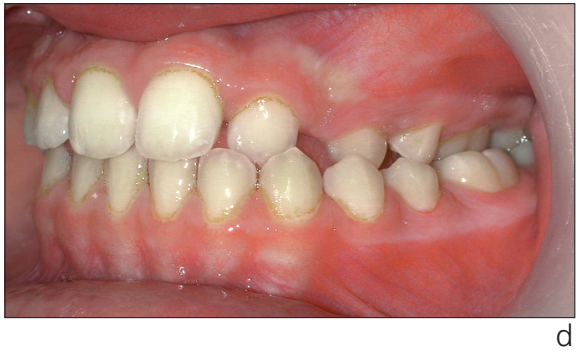

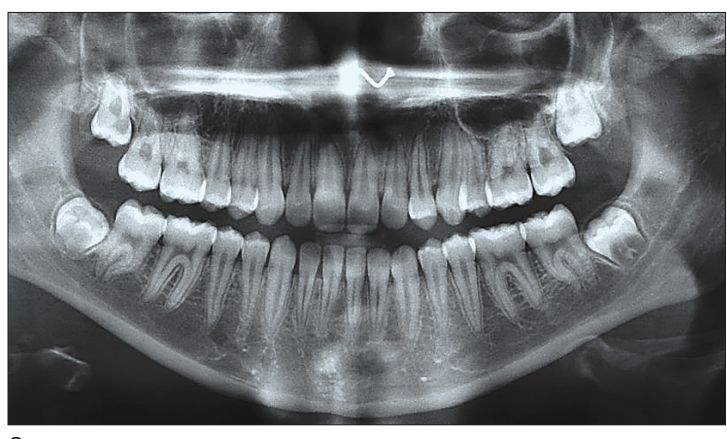

e
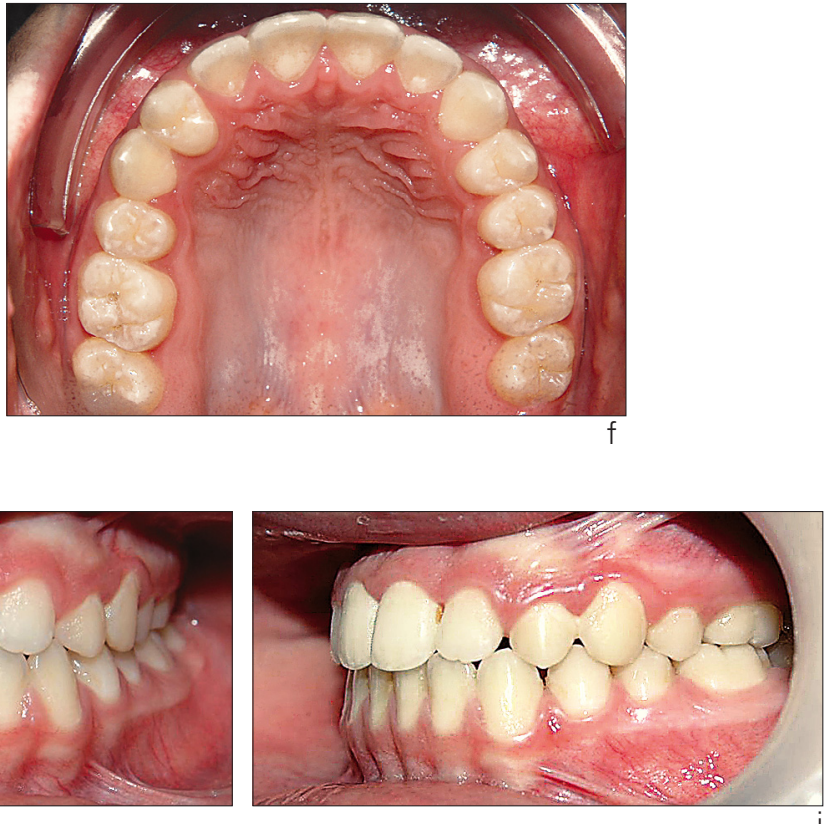

Figures 9 a to $i$

-a to d: panoramic $X$-ray and intraoral views before treatment;

-e to f: panoramic film and intraoral occlusal view after orthodontic treatment;

-g to i: intraoral views after orthodontic treatment that left transposed canine in place. 


\section{7 - 4 - Partial complete transpositions}

- In cases of complete transposition of a canine and a premolar if the treatment plan calls for the extraction of the four first premolars, obviously the treatment can conclude with all the canines in their proper position and the occlusion in a proper Class I relationship (fig. 10).

- In cases of partial complete transposition of a canine and a premolar accompanied by either congenitally absent laterals or peg-shaped laterals that cannot be conserved, it is possible to treat the problem orthodontically, closing

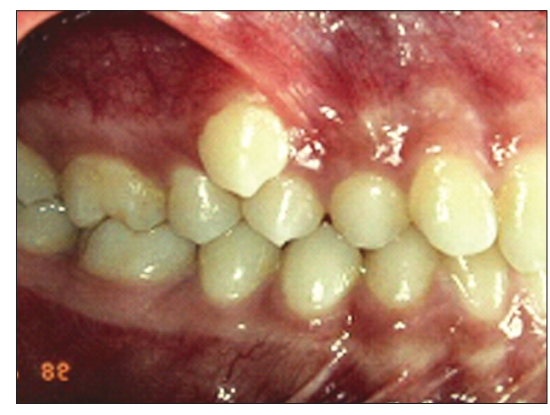
a

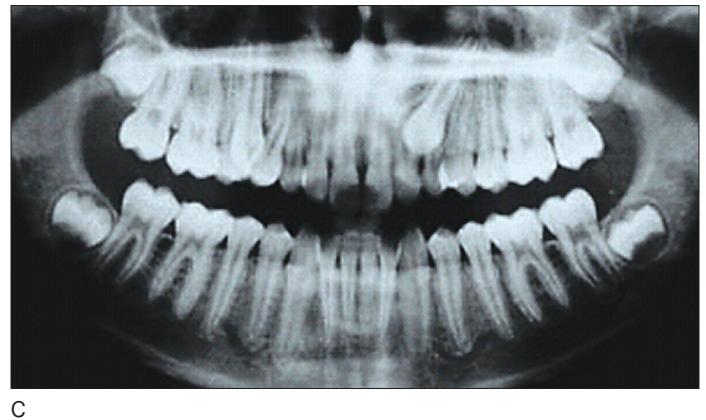

spaces, and moving the transposed canine into the lateral position thus avoiding putting a premolar in contact with a central incisor, which would have been both unaesthetic and non functional.

This solution, even though it is difficult and not without considerable inconveniences $17,21,25$, would seem to be preferable.

But the risks are considerable, including:

- root resorption $48,29,62,67$ so frequent that some authors assert that there are relationships between transpositions and dental anomalies as well as root resorption even if there is
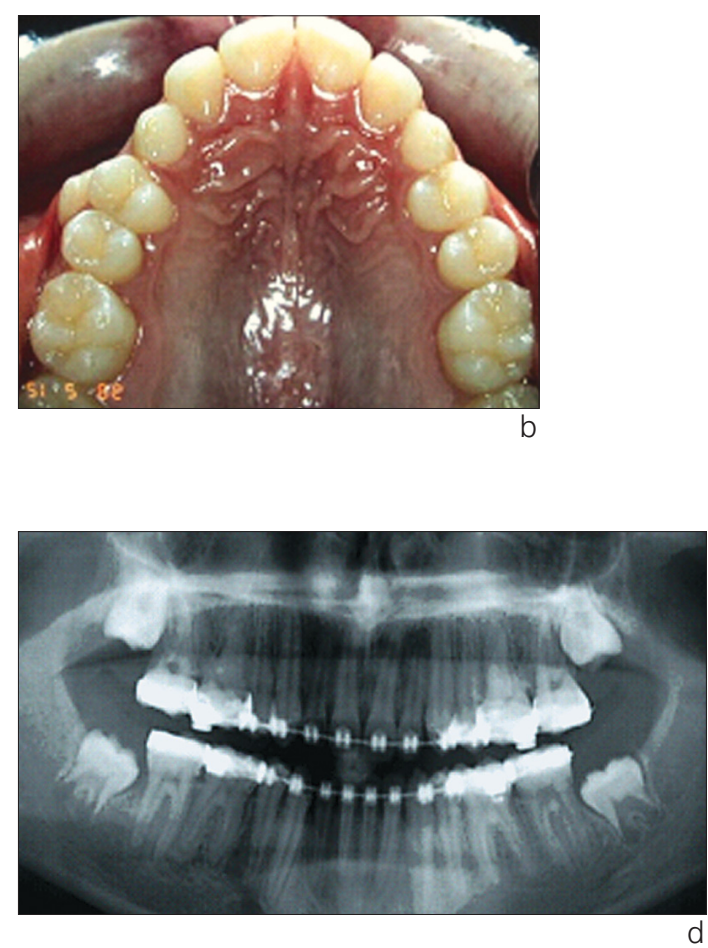

Figures 10 a to $d$

- $a$ and b: intraoral right buccal and occlusal views of complete transposition of canine and first premolar.

$-c$ and $d$ : pre-treatment and end of treatment panoramic X-rays of complete transposition of upper right canine and first premolar. 

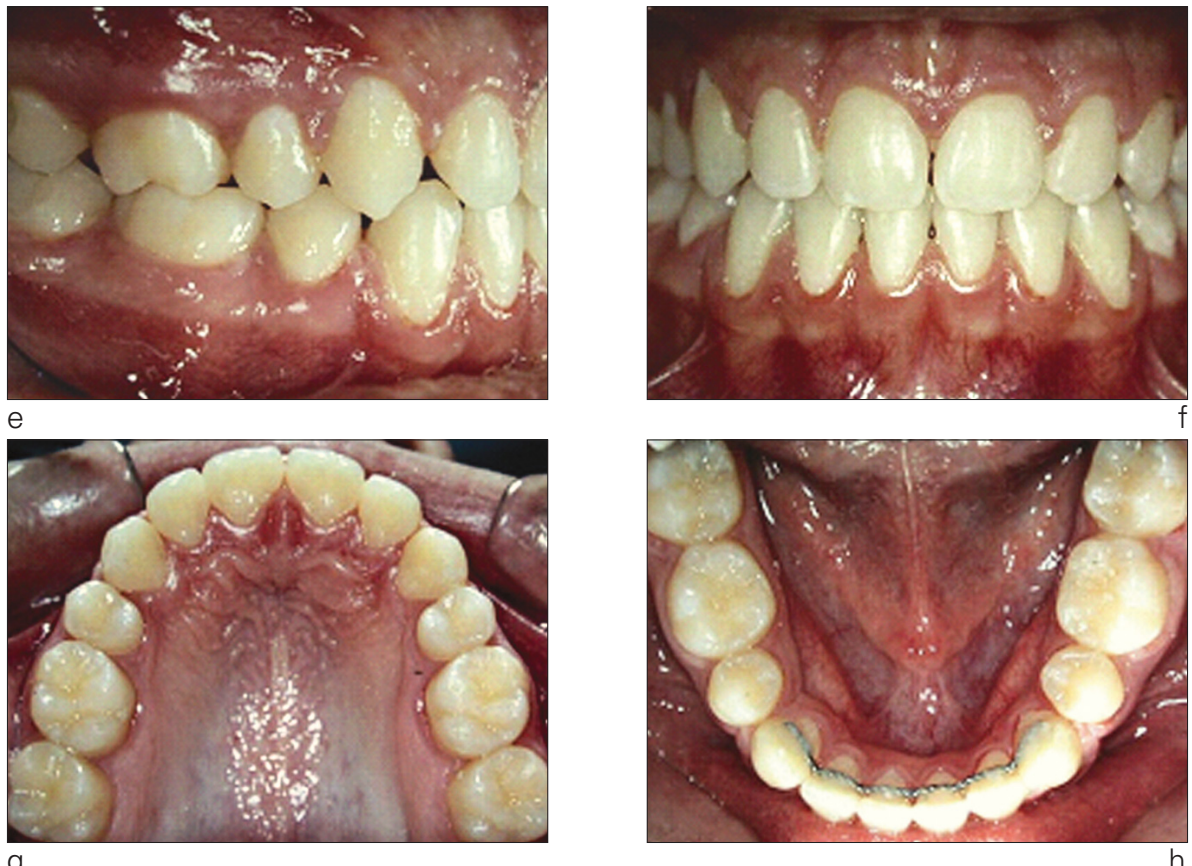

Figures 10 e to $h$

Intraoral views at the end of treatment. (case treated by Dr. S. Trichet.)

not yet any statistical confirmation of this opinion;

- loss of pulpal vitality;

- weakening of supporting soft tissues.

Despite all this, it is still possible to correct the transposition orthodontically by:

- intruding the canine;

- torqueing, or moving the premolar bodily toward the palate, using, Langlade suggests, a quad helix;

- then moving the canine mesially.

The patient depicted in figure 11 had a Class III malocclusion with congenitally absent maxillary incisors and an upper left canine and first pre- molar that were transposed. She was treated with a surgical-orthodontic protocol that, orthodontically, was accompanied by the undesirable side effects of root resorption and periodontal and occlusal difficulties associated with the closure of the lateral spaces.

So early detection of such a part complete transposition when the canine is still in a high position is desirable because, with early treatment these problems can be averted, especially if the patient has no congenitally absent teeth. The orthodontic technique for this early treatment would keep the canine in as high a position as possible (fig. 12). 


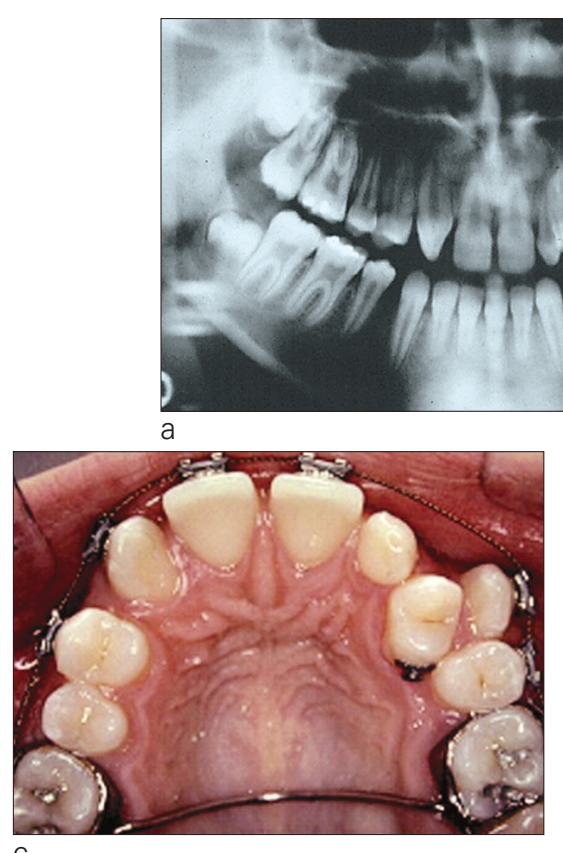

$\mathrm{C}$
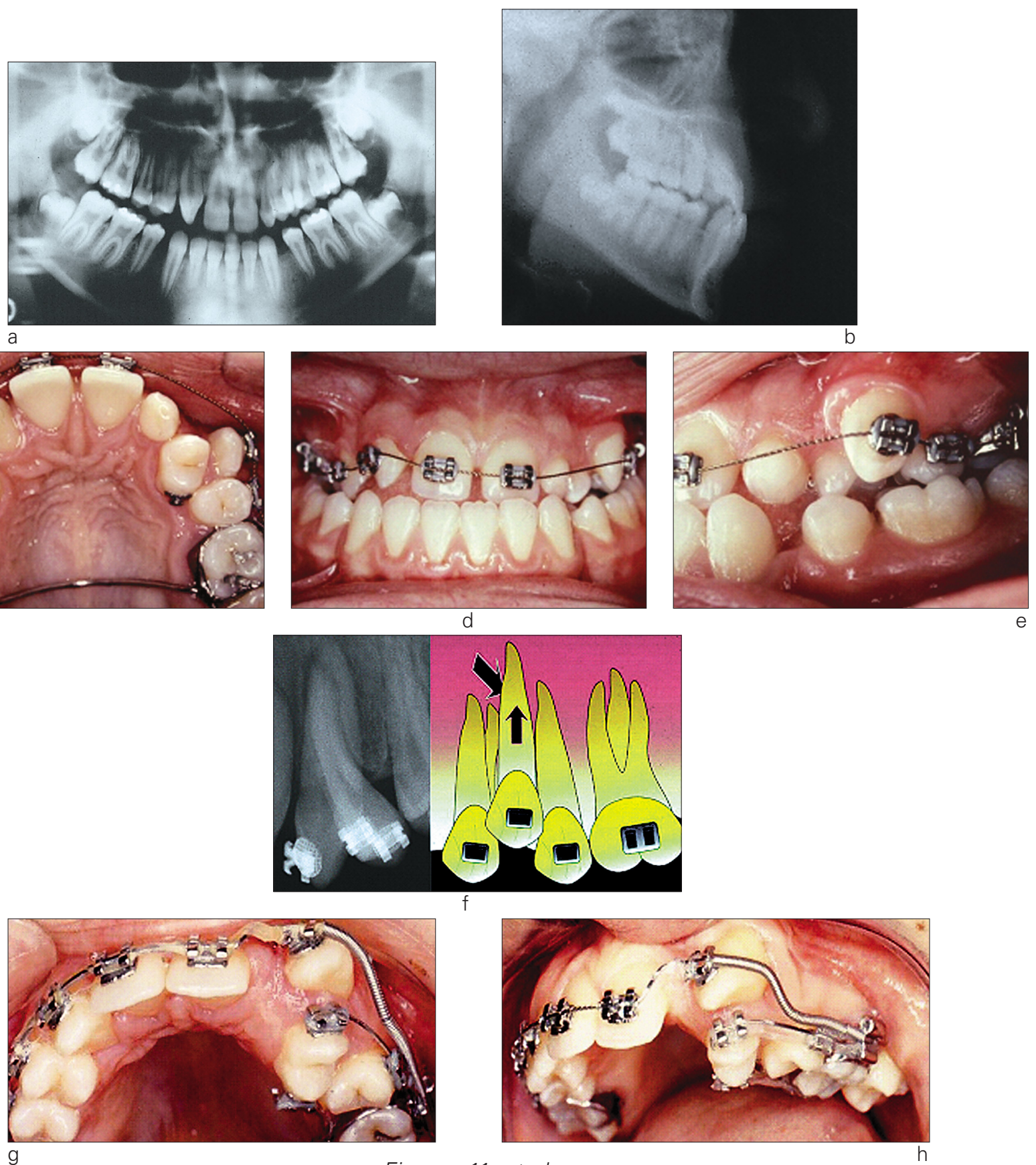

Figures 11 a to $h$

- a: panoramic film at the beginning of treatment;

- b: profile cephalogram at the beginning of treatment;

- c to e: orthodontic appliance at the beginning of treatment;

- $f$ to h: schema of the orthodontic appliance designed to:

- intrude the canine;

- torque the root of the first premolar palatally;

- move the canine mesially (case treated by Professor Canal). 

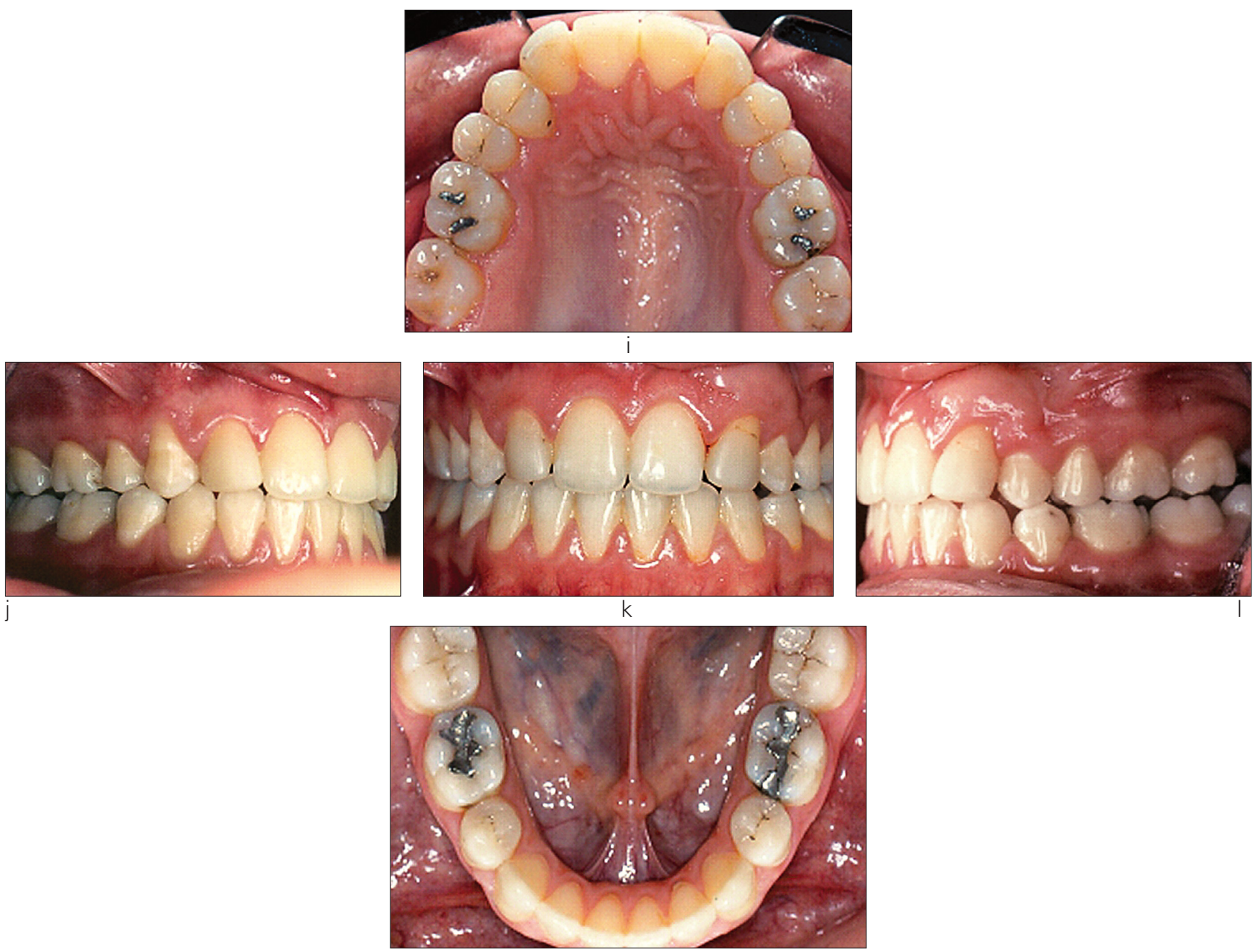

$\mathrm{m}$
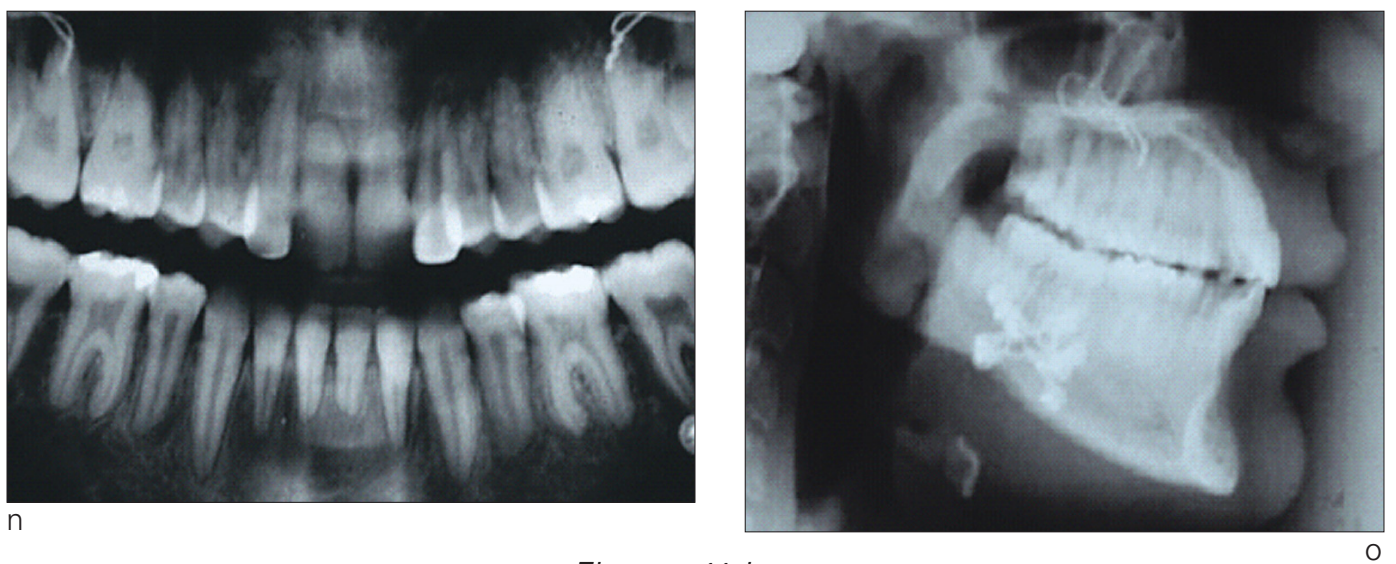

Figures 11 i to o

- i to m: intraoral views at the end of treatment;

- $n$ : panoramic film at the end of treatment;

- o: profile cephalogram at the end of treatment (case treated by Professor Canal). 


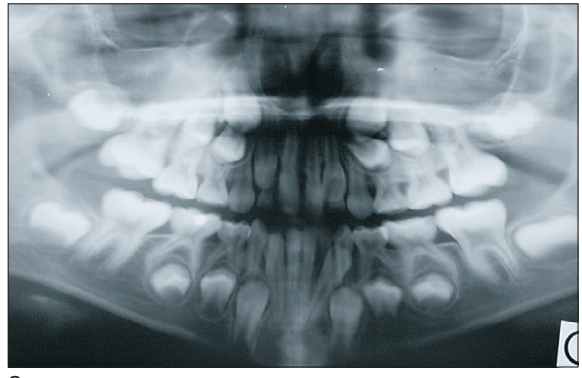

a
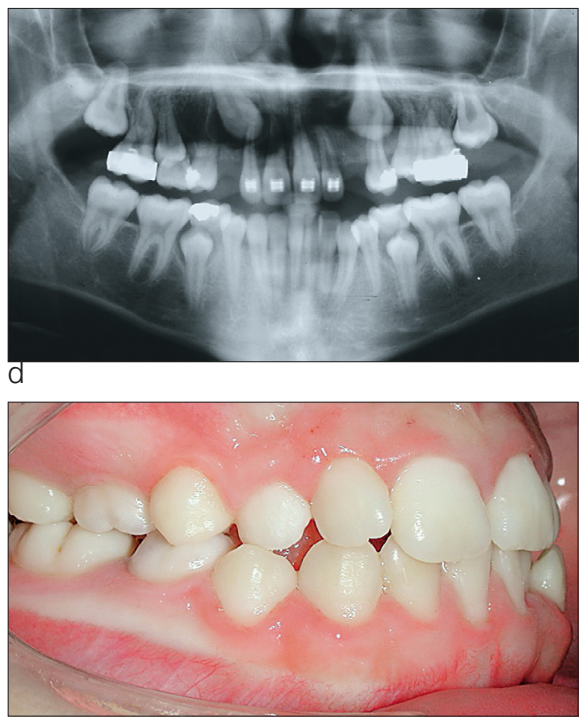

9

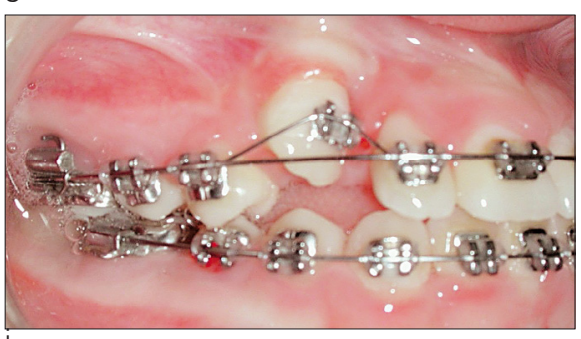$$
(7+3)+2
$$

$\mathrm{m}$

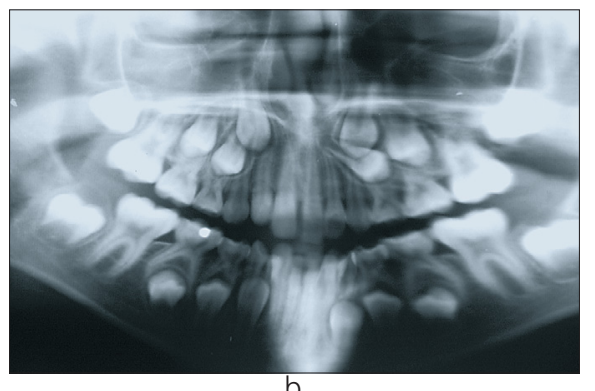

b
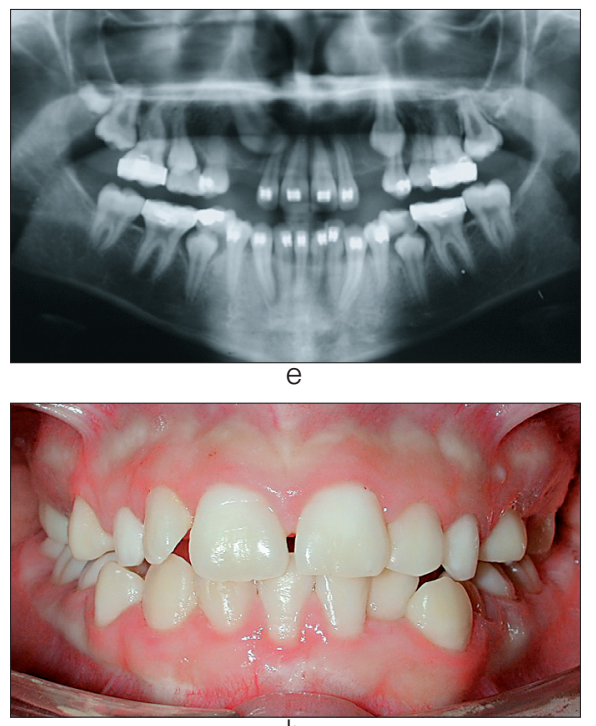

h
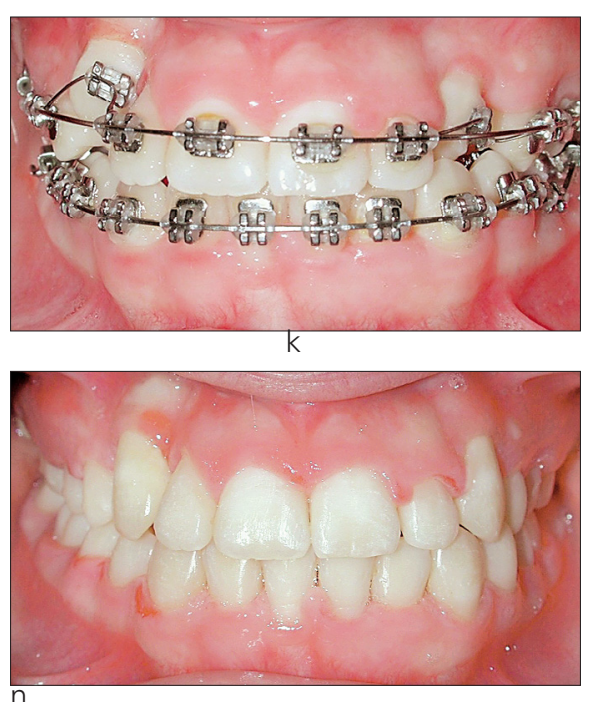

Figures 12 a to $o$
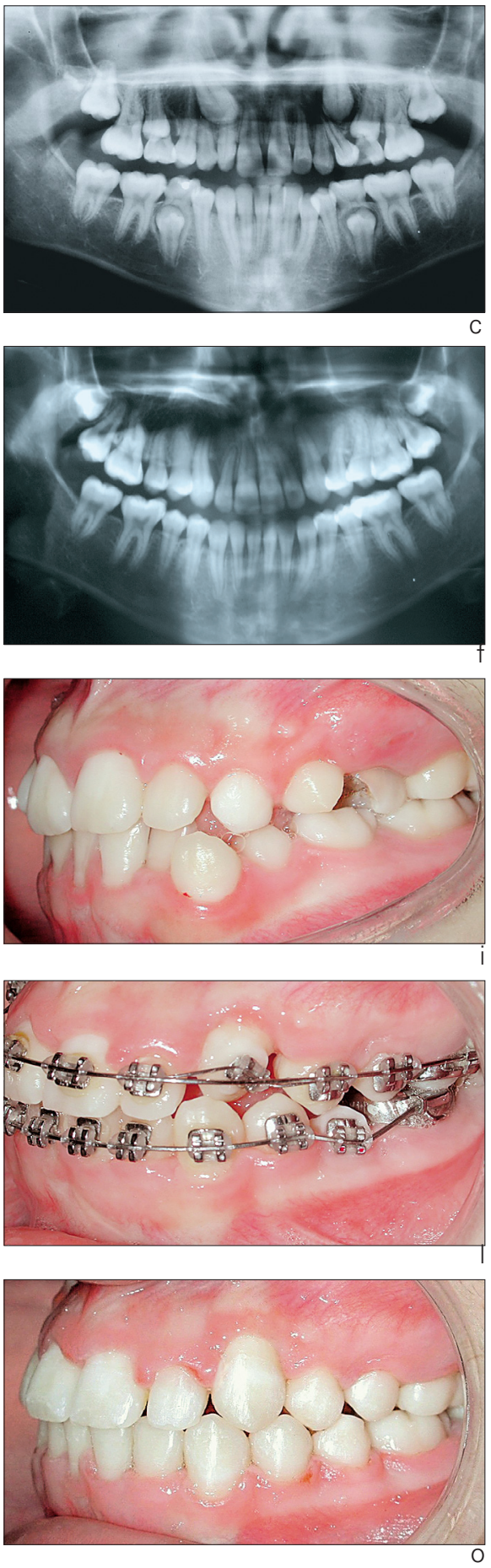

- a to f: panoramic films, before, during, and after treatment;

- $g$ to i: intraoral views before treatment;

- j to I: intraoral views during treatment;

- $m$ to o: intra-oral views at the end of treatment (case treated by Dr. L. Delsol). 


\section{8 - CONCLUSION}

The transposition of a maxillary canine is a rarely occurring phenomenon that can be accompanied by other dental anomalies such as congenitally absent or dwarfed lateral incisors.

Transposition can be incomplete, totally complete, or partially complete. Complete and even partially complete transpositions are difficult, and risky, to treat.

But when the anomaly is discovered early, treatment prospects improve, especially if the orthodontist can begin to move the unerupted transposed tooth when it is still in a high position.

But when the tooth is already erupted into the transposed position the better course of action may be simply to leave it between the two premolars and not attempt any orthodontic therapy for it.

However, thanks to advances in periodontal techniques and in orthodontic mechano-therapy with the improved anchorage of mini-screws and mini-plates, orthodontists may be able to treat almost all transposed teeth when appropriate. But, treatment of these conditions is still complicated and accompanied by multiple risks. Orthodontists, accordingly, should always make a careful risk/benefit evaluation before embarking on the treatment of a transposed tooth. Not infrequently this assessment will suggest that mechano-therapy be avoided.

\section{BIBLIOGRAPHY}

1. Allen Al. Use of the supraperiostal envelope in soft tissue grafting for root coverage. Int J Periodontics Restorative Dent 1994;4:217-315.

2. Altounian G. Mise en place de la canine maxillaire en dystopie palatine. Orthod Fr 1997; 68(1):291-6.

3. Al-Waheidi EMH. Transmigration of unerupted mandibular canines: A literature review and a report of five cases. Quintessence Int., 1996;27:27-31.

4. Arikan F, Nizam N, Sonmez S. 5-year longitudinal study of survival rate and periodontal parameter changes at sites of maxillary canine autotransplantation. J Periodontol 2008 Apr;79(4):595-602.

5. Artun J. and al. Long-term effect of thin inter dental alveolar bone on periodontal health after orthodontic treatment. Orthop 1987;91:125-130.

6. Artun J. and al. Long-term effect of root proximity on periodontal health after orthodontic treatment. J Periodont 1986;57:341-6.

7. Artun J, Ostenberg SK. Periodontal status of secondary crowded mandibular incisors. J Clin Periodont 1987;14:261-6.

8. Attia $Y$, Fayot $P$, Garcias D. Les canines transposées: étiologie, pathogénie. Orthod Fr 1986:57(2):605-27.

9. Attia Y, Fayot P. Les transpositions de canines. Traitement interceptif. Rev Orthop Dento Faciale 1987;21(2):251-9.

10. Azzi R, Etienne D. Recouvrement radiculaire et reconstruction papillaire par greffon conjonctif enfoui sous un lambeau vestibulaire tunnélisé et tracté coronairement. J. Parodontol Implantol Orale 1998;17:71-7.

11. Bassigny F. Les transpositions des canines permanentes et leur traitement: une approche préventive. Rev Orthop Dento Faciale 1990;24(2):151-64.

12. Bjorn H. Free transplantation of gingival propria. Tandlakarfob Tidning 1963;55:684. 
13. Borghetti A, Monnet-Corti V. Dégagement chirurgical des dents incluses. Chirurgie plastique parodontale, 2e édition. Paris: Cdp, 2008:449 p.

14. Brägger $U$. et al. The significance of alveolar bone in periodontal disease. A long-term observation in patients with cleft lip, alveolus and palate. J Clin Periodont 1990;17:379-84.

15. Brägger U, Lang N.P. The significance of bone periodontal disease. Seminars in Ortho-dontics 1996;2(1): 31-8.

16. Brownbill JW. and al. Ectopic eruption of transposed mandibular permanent lateral incisors beneath primary first molars; Case report. Aust Dent J 1994:1-3.

17. Ciarlantini R, Melsen B. Maxillary tooth transposition: Correct or accept? Am J Orthod Dentofacial Orthop 2007;132:385-94

18. Chattopadhyay A, Srinivas K. Transposition of the teeth and genetic etiology. Angle Orthod 1966;66:147-52.

19. Darmon ML. Les transpositions canine-prémolaire au maxillaire: considérations théoriques, dépistage et traitement précoce. Thèse doctorat en chirurgie dentaire, Paris VII, 2001.

20. Exbrayat P. Etude prospective de 95 cas consécutifs de désinclusion chirurgico-orthodontique de canines. J Parodontol Implantol Orale 2000;19:7-17.

21. Giacomet F, Araujo T. Orthodontic correction of maxillary canine-first premolar transposition. Am J Orthod Dentofacial Orthop 2009;136:115-23.

22. Giacomet F, Araujo MT. Orthodontic correction of a maxillary canine-first premolar transposition. Am J Orthod Dentofacial Orthop 2009 Jul;136(1):115-23.

23. Genon P, Koskas H. Actualités sur la chirurgie muco-gingivale III. Indictions, conclusion. J Parodontol 1985;4:329-342.

24. Guyomard F. Conditions de la réussite des interventions de chirurgie muco-gingivale au cours du traitement orthodontique. Orthod Fr 1998;69:131-40.

25. Halazonetis DJ. Horizontally impacted maxillary premolar and bilateral canine transposition. Am J Orthod Dentofacial Orthop 2009;135:380-9.

26. Hitchin AD. The impacted maxillary canine. Br Dent J 1956;100:1-12.

27. Järvinen S. Mandibular incisor-cuspid transposition: A survey. J Pedodont 1982;6:159-63.

28. Joshi MR, Bhatt NA. Canine transposition. Oral Surg 1971;31:49-54.

29. Kavadia-Tsatala S. and al. Tooth transpositions associated with dental anomalies and treatment management in a sample of orthodontic patients. J Clin Periodont 2003;28(1):19-25.

30. Korbendau JM, Guyomard F. Apport de la chirurgie parodontale à la mise en place des canines en dystopie vestibulaire. Rev Orthop Dent Fac 1980;14:459-77.

31. Korbendau JM, Guyomard F. Chirurgie parodontale orthodontique. Paris: Cdp, 1998:247p.

32. Lacoste JL. Désinclusion et mise en place des dents retenues. Encycl Med Chir Odontologie 1988;23-492-A-10.

33. Langer B, Langer L. Sub-epithelial connective tissue graft for treatment of gingival recession. Dent Clin North Am 1993;37:243-64.

34. Langlade M. Thérapeutique orthodontique. Paris: Maloine, 1986:863p.

35. Laptook T, Silling G. Canine transposition - Approaches to treatment. J Am Dent Ass 1983;107:746-8.

36. Loreille JP. Gencive attachée et mise en place des dents incluses: indications de la chirurgie pré-orthodontique. J Parodontol 1984;3:397-407.

37. Lukacs JR. Canine transposition in prehistoric Pakistan: Bronze age and iron age case reports. Angle Orthodont 1998;685:475-80.

38. Mader C, Konzelman JL. Transposition of teeth. J Am Dent Ass 1979;98: 412-13.

39. Maynard G. The rational for mucogingival therapy in the child and adolescent. Int $J$ Periodontics Restorative Dent 1987;1:37-52.

40. Maynard JG, Wilson RD. Physiologic dimensions of the periodontium significant to the restorative dentist. J Periodontol 1979;50:174-4.

41. Maynard JG, Wilson RD. Diagnosis and management of mucogingival problems in children. Dent Clin North Amer 1980;24:683-703. 
42. Miel EM. Observation sur un cas très rare de transposition de dents. J Méd Chir Pharm 1817; 40:88-97.

43. Miller PD. A classification of marginal tissue recession. Int J Periodontics Restorative Dent 1985;5(2):9-13.

44. Monnet-Corti V, Borghetti A. Chirurgie plastique parodontale et orthodontie. J Parodontol Implantol Orale 2000;19:253-66.

45. Nelson GC. Maxillary canine-third premolar transposition in a prehistoric population from Santa Cruz Island, California. Am J Phys Anthropol 1992;88:134-44.

46. Niczky E. and al. Transpozicie. Cesk Stomatol 1967;67:227-33.

47. Papdopoulos MA, Karagiannis V. Assessment of characteristic features and dental anomalies accompanying tooth transposition: A meta-analysis. Am J Orthod Dentofacial Orthop 2009;136:308-9.

48. Parker WS. Transposed premolar, canines and lateral incisors. Am J Orthodont Dentofac Orthop 1990;97:431-48.

49. Peck L, Peck $S$, Attia Y. Maxillary canine-first premolar transposition associated dental anomalies and genetic basis. Angle Orthodont 1993;63:99-109.

50. Peck S, Peck L. Classification of maxillary tooth transpositions. Am J Orthodont Dentofac Orthop 1995;107:505-17.

51. Peck S. and al. Prevalence of tooth agenesis and peg-shaped maxillary lateral incisor associated with palatally displaced canine (PDC) anomaly. Am J Orthodont Dentofac Orthop 1996;110:441-3.

52. Peck S. and al. Mandibular lateral incisor - canine transposition in monozygotic twins. ASDC J Dent Child 1997;64:409-13.

53. Peck S. and al. Mandibular lateral incisor - canine transposition, concomitant dental anomalies and genetic control. Angle Orthod 1998;68(5):455-66.

54. Peck S. On the phenomenon of intraosseous migration of no erupting teeth. Am J Orthod Dentofac Orthop 1998;113:515-7.

55. Perezt B, Arad A. Bilateral transposition of maxillary canine and first premolars: case report. Quintessence, 1992;23:345-8.

56. Platzer KM. Mandibular incisor-canine transposition; J Am Dent Ass 1968;76:778-84.

57. Plunkett DJ. and al. A study of transposed canine in a sample of orthodontic patients. $\mathrm{Br} \mathrm{J}$ Orthodont 1998;25:203-8.

58. Ruellas AC, De Oliveira AM, Pithon MM. Transposition of a canine to the extraction site of a dilacerated maxillary central incisor. Am J Orthod Dentofacial Orthop 2009;135:S133-9.

59. Ruprecht $A$. and al. The incidence of the transposition of teeth in dental patients. J Pedo 1985;9:244-9.

60. Sandham A, Harvie H. Ectopic eruption of the maxillary canine resulting in transposition with adjacent teeth. Tandlaegebladet, 1985;89:9-11.

61. Shanmuhasuntharam P, Boon LC. Transmigration of permanent mandibular canines, Case report. Aust Dent J 1991;36:209-13.

62. Shapira Y, Kuftinec MM. Orthodontic management of mandibular canine-incisor transposition. Am J Orthod 1983;83:271-76.

63. Shapira Y, Kuftinec MM. Tooth transposition - A review of literature and treatment considerations. Angle Orthod 1989;59:271-76.

64. Thilander B, Jakobson SO. Local factors in impaction of maxillary canines. Acta Odont Scand 1968;26:145-68.

65. Thilander B. and al. Bone regeneration in alveolar bone dehiscence related to orthodontic tooth mouvements. Eur Orthodont J 1983;5:105-14.

66. Wasserstein A, Brezniak N. Incomplete canine transposition and maxillary central incisor impaction. A case report. Am J Orthod Dentofac Orthop 1997;111:635-9.

67. Weeks EC, Power SM. The presentations of management of transposed teeth. Brit Dent J 1996;181:421-25.

68. Wood Fl. Developmental anomaly with associated canine transposition. Brit Dent J 1958; 104:212. 